\title{
Rapid recovery of an island population of the threatened South Island Saddleback Philesturnus c. carunculatus after a pathogen outbreak
}

\author{
KATRINA A. HALE and JAMES V. BRISKIE
}

\section{Summary}

The small size of many island populations of endangered birds, together with their high density, low genetic diversity and naivety to introduced pathogens, may render them vulnerable to disease epidemics. Such an outbreak occurred in an isolated population of threatened South Island Saddleback Philesturnus c. carunculatus on Motuara Island, New Zealand. In 2002, the population dropped from $\sim 130$ birds to $\sim 60$ birds, apparently from an outbreak of systemic coccidiosis. However, within three years the population had recovered to $>130$ individuals. This appears to be the carrying capacity of the island as areas left vacant after the crash were reoccupied by the end of the third year. Reproductive success of saddlebacks was similar across the three years following the crash and there were no significant differences in clutch size, nesting success or fledgling mass as the population increased. In contrast, feather mite loads increased and leucocyte counts changed significantly in both adult and nestling saddlebacks as the population recovered, suggesting higher population densities may reduce immunocompetence. Although reproductive success did not appear directly affected by population size, our observations indicate increased levels of stress at high densities could render saddlebacks susceptible to recurring disease outbreaks.

\section{Introduction}

One of the most dramatic examples of the effect of disease on population dynamics is the extinction of over half the Hawaiian terrestrial avifauna due to the introduction of avian malaria and pox (Warner 1968; van Riper et al. 1986). Parasitic organisms and other pathogens are now considered a serious threat to the survival of many endangered species (Altizer et al. 2001). Insular populations are expected to be particularly prone to disease outbreaks and extinction owing to low genetic diversity as a result of bottlenecks during their establishment and because island ecosystems are more susceptible to invasion by new diseases (Frankham 1998; Altizer et al. 2001). Furthermore, insular populations often exist at high densities as a result of the small size and isolation of many island habitats. High densities may lead to elevated stress levels which in turn could lead to reductions in immune function, reducing the threshold above which a population may succumb to disease; the result can be population crashes and possible local extinction (Miller 1994; Wikelski et al. 2004).

A recent crash of a South Island Saddleback Philesturnus c. carunculatus population may provide one such example of the vulnerability of isolated island populations to pathogens. The South Island Saddleback is a medium-sized, forest passerine that is endemic to New Zealand (a second subspecies, P. c. rufusator, occurs on North Island). Saddlebacks were once widespread 
across New Zealand but declined with the introduction of mammalian predators in the 19th century and now survive only on predator-free offshore islands. There are currently 27 island populations of saddlebacks scattered around the coast of New Zealand (Hooson and Jamieson 2003), including a population established from 26 founders released in 1994 on Motuara Island in the Marlborough Sounds of the South Island. By late 2001, the population had reached over 130 birds and was nearing the carrying capacity of the island (Hooson and Jamieson 2003). However, by March 2002 a survey of the population revealed it had declined to $\sim 60$ birds (pers. obs.). Individuals captured at this time were infested with hippoboscid flies ( $>35$ flies per individual) and some exhibited lesions on the face, cloaca and wings, while autopsies revealed the birds were infected with severe systemic coccidiosis. It seems likely that the population crash at this time was related to these and/or additional pathogens.

Given the importance of islands to the conservation of endangered native birds in New Zealand and elsewhere, understanding whether small and isolated populations like that of saddlebacks on Motuara Island can recover after disease outbreaks is critical if the use of islands is to remain a viable conservation strategy in the long-term. Our aim in this study was to monitor the postcrash population on Motuara Island to determine: (I) how long it required before the population recovered to its pre-crash level; (2) whether reproductive success changed with increasing population size as the population recovered, and (3) whether parasite burdens and the ability of birds to mount an immune response changed as the population recovered.

\section{Methods}

\section{Study population}

Motuara Island is a small island (59 ha) located off the northern coast of South Island $\left(41^{\circ} 5^{\prime} \mathrm{S}\right.$ $174^{\circ} 16^{\prime} \mathrm{E}$ ), and lies $1.45 \mathrm{~km}$ from the nearest mainland. The island was cleared for farming in the $19^{\text {th }}$ century but is now a nature reserve and the entire island is covered with regenerated native forest. Saddlebacks feed mainly on the forest floor on a diet of invertebrates and fruits (Heather and Robertson 2000), and most of the island appears to be suitable habitat for saddleback. However, saddlebacks are poor fliers and unable to disperse off islands (such as Motuara) isolated by open bodies of water greater than a few hundred metres (Newman 1980). Thus, the closed nature of the Motuara Island population meant we could be sure that changes in population size were not affected by either immigration or emigration.

Saddlebacks are relatively tame and we were able to readily locate and monitor birds over most of the island. Both male and female adult saddlebacks ( $>2$ years old) have jet-black plumage with a chestnut-coloured saddle on the back and fleshy orange wattles on either side of the bill but can be sexed in the hand through size differences (Heather and Robertson 2000). Sub-adult South Island saddlebacks ( $>_{1}$ year but $<_{2}$ years old) are a rusty brown colour until they moult into adult plumage at two years of age, making them distinguishable from adults. However, apart from the different plumage, sub-adult individuals are the same size as adults and begin breeding in their first year (unpubl. data). Adult birds maintain a similar plumage after two years of age. As there are no known differences in breeding success with age in saddlebacks, both sub-adult and older birds were combined in this study and treated as a single group to distinguish them from nestlings or birds less than one year old.

\section{Population size}

Population census data for the years 1994-1997 and 2001 was collated from published data (Hooson and Jamieson 2003; Lovegrove 1996a) and from personal communication with the Department of Conservation (W. Cash, Marlborough Conservancy). Both involved similar methods of searching the entire island and mapping locations of birds to estimate total number 
present. Note that detailed surveys were not carried out between 1998 and 2000 although it was known the populations were continuing to expand. Population surveys from 2002 to 2006 were carried out by us and involved repeated searches of the island. Surveys began at the start of the breeding season and continued until all known nestlings had fledged (about six months later). The final population estimate recorded for each year was taken at the beginning of autumn (April/ May) when the breeding season was complete. Total population counts included both adults and juveniles hatched that breeding season. As most saddlebacks were colour-banded for individual identification we were able to map out territories over most of the island. A small percentage $(\sim 10-20 \%)$ of birds were unbanded each year, and it is possible some individuals may have been counted twice. However, the high site fidelity of banded individuals suggests unbanded birds encountered repeatedly in the same location were likely the same individuals, making it less likely that we counted them more than once.

\section{Reproductive success}

We searched all accessible areas on Motuara Island ( 90\% of the island) from October 2002 to April 2005 to locate South Island Saddleback nests. This period encompassed the three breeding seasons immediately following the population crash in March 2002. Nests were visited every 2-3 days to monitor their progress. Clutch size and fledging success was recorded in accessible nests and pre-fledge nestling mass was obtained when the nestlings were aged 17 days ( \pm 2 days). At this point the nestlings are fully feathered. To avoid pseudo-replication, measures of body mass from chicks from the same nest were averaged. Each nestling was banded with a metal ring and colour combination to code for the hatch year. A blood sample was taken by brachial venipuncture from each nestling for analysis of blood parameters (see below). A post-fledging mass was obtained from independent young caught at the end of breeding season between February and April each year. Nestlings could not be sexed but the sex of fledged hatch-year birds are distinguishable by differences in tarsus length and body mass (Nillson 1978).

Egg success, nest success and annual reproductive success were calculated following Bertram (2000). Egg success was defined as the proportion of eggs that produced young, and was calculated as the number of young that left the nest divided by the total number of eggs laid. Nest success was defined as the proportion of clutches that produced young, and was calculated as the total number of clutches that produced young divided by the total number of clutches. Annual reproductive success (ARS) was calculated as the number of broods successfully reared per female (defined as ARS [b]) and the number of young successfully reared per female (defined as ARS [k]; see Bertram 2000). Hooson and Jamieson (2004) collected some data on reproductive success of Motuara Island saddlebacks in the year before the crash, and where possible we compared our results with this earlier work.

\section{Parasite analysis}

Between November 2002 and August 2005, we caught 101 saddlebacks ( 33 adults and 75 subadults) for the analysis of parasite loads. We caught birds with mist nets and all birds were banded with a metal band and individual colour combination. To avoid the confounding effects of repeated captures, no birds were sampled for parasite loads more than once. An estimate of feather mite density was obtained for each individual by visually examining the primary feathers of the left wing and giving a categorical score for each bird from $0-5$, where: $0=$ no feather mites; $1=0-10$ feather mites; $2=10-100$ feather mites; $3=100-1,00$ feather mites; $4=1,000-10,000$ feather mites and $5=10,000+$ feather mites. This score was obtained by roughly counting the number of mites present in an infested area of a feather and multiplying it by the relative area of mite infestation over the entire surface area of the primaries. The number of hippoboscid flies (Ornithomya spp. and Ornithoica spp.) seen on or flying off the bird were also counted. Hippoboscid flies are obligate blood-feeding ectoparasites and are known to be vectors of a number 
of blood-borne diseases (Hutson 1984). Faecal samples were collected from 6o individuals ( 15 adults and 45 sub-adults) from holding bags (the birds usually defecated while being held in cloth bags) for analysis for gastrointestinal nematodes and the protozoan parasite coccidia. Faecal floatation was used to obtain estimates of coccidia and nematode burdens and these were carried out at a commercial laboratory (New Zealand Veterinary Pathology Ltd, Hamilton, NZ). Sporulation of the coccidia oocysts identified all species to the genus Isospora (K. Townsend, pers. comm.).

\section{White blood cell analysis}

The relative numbers and ratios of each of the various types of white blood cells have been shown to provide a relative means of assessing the level of immunocompetence and stress in birds (Ots and Horak 1998; Horak et al. 1999; Fudge 2000). A leucocyte count includes all white blood cells and gives an indication of the health status of the individual at the time of sampling. A high count, or leucocytosis, is characteristic of inflammatory diseases and parasitic infection (Woerpel and Rosskopf 1984; Fudge 2000). The different types of leucocytes (lymphocytes, heterophils, basophils and eosinophils) have differing functions in the avian immune system, but only the roles of lymphocytes and heterophils are well understood. Lymphocytes work to generate a pathogen-specific immune response. Within the 'normal' range of a lymphocyte count for a species (defined as values inside the $90 \%$ confidence limits), a high concentration of lymphocytes circulating in the peripheral blood has been linked with higher immunocompetence (e.g. Hale and Briskie 2007; Horak et al. 1999). However, lymphocyte concentrations outside the normal range are difficult to interpret and may indicate any disorder ranging from viral and bacterial infections, severe stress or parasitic infection (Ots and Horak 1998; Horak et al. 1999). For the purposes of this study, any individuals with counts outside of the normal ranges were omitted from our statistical analyses. Heterophils are phagocytic cells and high numbers can indicate either inflammation and/or stress (Fudge 2000). They play a key role in initiating the innate immune response and the recognition of pathogens by detecting molecules unique to invading organisms (Swaggerty et al. 2005).

Between November 2002 and August 2005 we sampled 108 saddlebacks ( 33 adults and 75 subadults) for white blood cell analysis. No individual was sampled for blood analysis more than once. For the purposes of analysis, we defined two sampling seasons: spring/summer (OctoberMarch) and autumn/winter (April-September). This corresponds with the breeding and postbreeding season, respectively. To measure leucocyte parameters, we collected a drop of blood from the right wing of each individual via brachial venipuncture. Blood was smeared onto a glass slide, fixed in methanol and stained using a modified May-Grünwald Giemsa staining method (Lucas and Jamroz 1961). Blood smears were then viewed under a light microscope and the following measured: (1) a leucocyte estimate, which gives an estimated leucocyte count (Fudge 2000), and (2) a leucocyte differential. The leucocyte estimate was calculated by counting all white blood cells in ten consecutive fields of view for each slide at a magnification of $400 x$. Counts were averaged to give an estimate for each individual (Walberg 2001). To obtain a leucocyte differential and thus estimate numbers of lymphocytes, heterophils, basophils and eosinophils, each blood smear was examined under oil immersion (Iooox magnification) and the relative frequency of the five different types of leucocytes determined for a total of 100 leucocytes. We surveyed the blood smear using a cross-sectional method (down-across-up-across-down, etc.) identifying each type of leucocyte when encountered until a total of 100 leucocytes were counted. The heterophil/ lymphocyte ratio (H/L), which has been used as an index of physiological stress in both poultry (Gross and Siegel 1983; Maxwell 1993) and wild birds (Tompkins et al. 2006), was then calculated by dividing the number of heterophils by the number of lymphocytes. Finally, we scanned the blood smear for three minutes using the same cross-sectional method to detect any blood-borne parasites. 


\section{Statistical analysis}

We performed all statistical analyses in Statistica 6 (StatsSoft, Inc.). Any significant outliers in the leucocyte data for both adults and chicks were identified using Grubbs analysis and removed if significant $(P<0.05)$. We used general linear models, using sequential type I sums of squares, to determine if there was significant variation between years in leucocyte counts, H/L ratio, and counts of lymphocytes, heterophils, eosinophils and basophils taking into account differences in seasons and sexes. Using model simplification we built a minimum adequate model to determine which variable(s) best explained the variance in the above leucocyte parameters. This was done by initially including all proposed predictor variables and interactions and removing those that were responsible for the lowest reduction in variance until all remaining predictors were significant $(P<0.05)$. We used one-way ANOVAs to determine any differences in leucocyte counts and the counts of lymphocytes, heterophils, eosinophils and basophils between years for nestlings. Since the data could not be normalised, we used the non-parametric Kruskal-Wallis test to compare reproductive success, pre-fledgling mass and parasite counts between years. We used a general linear model to determine if post-fledgling juvenile mass differed between sexes and years. A Fisher exact test was used to determine if there was any significant difference in survival of fledglings from the first two breeding seasons (2001/02 and 2002/03).

\section{Results}

\section{Population recovery after the crash}

Population surveys following the crash showed a rapid recovery of the Motuara Island saddleback population with the total number of birds increasing from 64 to 115 individuals in 2003, and to 128 individuals in 2004. By 2005, three years after the crash, the population was estimated to be 134 individuals, similar to the pre-crash estimate of 130 individuals (Figure 1 ). The number of hatching-year birds added to the population each year varied from 51 birds added in $2003(44.3 \%$ of the population), 40 birds added in 2004 (31.3\% of the population), and 42 birds added in 2005 ( $31.3 \%$ of the population). By the end of the third breeding season, the proportion of the population comprised of birds hatched after the crash had increased to $68.7 \%$ of the total

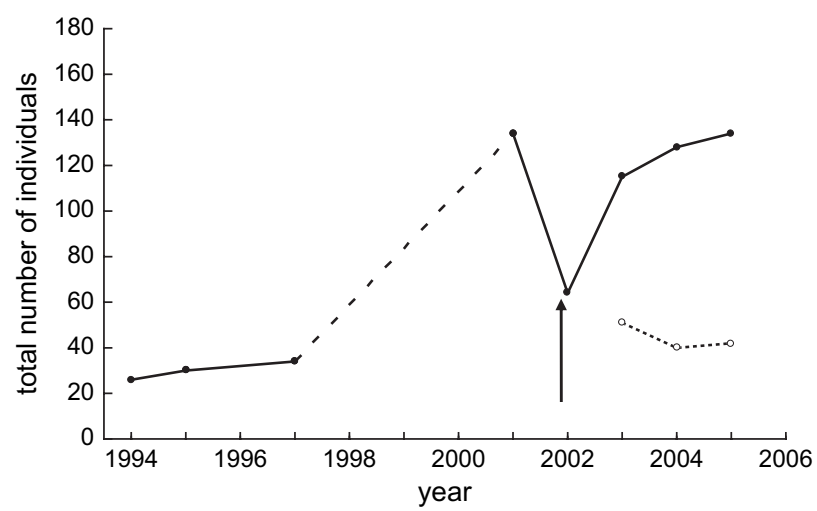

Figure 1. Population growth of the Motuara Island saddleback population from the year of reintroduction to present (closed circle solid line). The arrow indicates the period in which the population crash occurred. The dashed line represents the period over which no population density estimates were made although it was known the population was growing. The dotted line with open circles illustrates the number of juveniles produced each year following the crash. 
population. However, the number of nestlings recruited to the breeding populations declined from 32 birds in the 2003 breeding season to just 18 birds in the 2004 season, suggesting decreasing recruitment as the population increased.

\section{Changes in reproductive success between years}

Reproductive success did not differ among the three years following the population crash, nor did it differ from published information collected before the crash (Table 1; Hooson and Jamieson 2004). Mean clutch size, egg success, nest success, and the number of fledglings per successful nest, did not differ significantly across the three breeding seasons after the crash (Kruskal-Wallis test, all $P>0.05$ : Table 1 ). Similarly, annual reproductive success as estimated by the number of broods fledged per females [ARS(b)] and the number of fledglings per female [ARS $(\mathrm{k})]$, did not differ significantly across the three breeding seasons (Kruskal-Wallis test, both $P>0.05$ : Table 1 ). Second broods are generally uncommon in established South Island Saddleback populations (Higgins et al. 2006) and none were found in the first breeding season after the crash (Table 1 ), although small numbers of second broods were found in the two following years.

There was no significant difference between breeding seasons in juvenile pre-fledge body mass (Kruskal-Wallis test, $P>0.05$ ), and although there was a slight decline in post-fledge body mass from the second to third breeding season, there was no significant difference in post-fledge body mass between breeding seasons $\left(\mathrm{F}_{1,29}=2.82, \mathrm{P}>0.05\right.$; Table 2$)$. Survival of fledglings from the first two breeding seasons after the crash to approximately three months after fledging was $51 \%$ $(18 / 35)$ and $31 \%(11 / 35)$, respectively. This difference is not significant although our sample size and power to detect a difference is small (Two-tailed Fisher exact test: $P=0.11$ ).

\section{Changes in parasite loads between years}

Hippoboscid flies were found on adult saddleback in all three years; however there was no significant difference in prevalence between years $\left(\mathrm{H}_{2,104}=5.45, P>0.05\right)$ with the average number of flies per individual ranging between one and four (Figure 2a). In contrast, there was a significant difference in feather mite scores between years with individuals exhibiting higher loads three years after the crash than in the first two years after the crash $\left(\mathrm{H}_{2, \mathrm{IO} 4}=5.45\right.$,

Table 1. Measures of reproductive success in the Motuara Island saddleback population in the three years following a population crash. ARS is annual reproductive success with ARS(b) the number of broods successfully reared per female, and ARS(k) the number of young successfully reared per female. First and second broods are listed separately except for the 2002/03 breeding season in which no second broods were found. The data from 2001/02 were taken from Hooson and Jamieson (2004) and were collected before the population crash.

\begin{tabular}{|c|c|c|c|c|c|c|c|c|}
\hline \multirow{2}{*}{$\begin{array}{l}\text { breeding } \\
\text { season }\end{array}$} & \multirow{2}{*}{$\begin{array}{l}\text { \# breeding } \\
\text { females }\end{array}$} & \multirow{2}{*}{$\begin{array}{l}\text { total \# nest } \\
\text { attempts } \\
\text { monitored }\end{array}$} & \multicolumn{6}{|c|}{ reproductive success } \\
\hline & & & $\begin{array}{l}\text { mean clutch } \\
\text { size }\end{array}$ & $\begin{array}{l}\text { egg } \\
\text { success }\end{array}$ & $\begin{array}{l}\text { nest } \\
\text { success }\end{array}$ & $\begin{array}{l}\text { \# fledglings } \\
\text { per successful } \\
\text { nest }\end{array}$ & ARS(b) & ARS(k) \\
\hline 2001/O2 & 14 & 15 & 2.00 & 0.46 & - & 0.90 & - & 0.90 \\
\hline $2002 / 03$ & 16 & 19 & 1.89 & 0.75 & 0.76 & 1.86 & 0.906 & 1.69 \\
\hline \multirow[t]{3}{*}{$2003 / 04$} & 21 & 27 & 1.85 & 0.76 & 0.76 & 1.85 & 0.976 & 1.81 \\
\hline & & $23^{*}$ & 1.86 & 0.77 & 0.76 & 1.89 & & \\
\hline & & $4^{* *}$ & 1.85 & 0.71 & 0.75 & 1.67 & & \\
\hline \multirow[t]{3}{*}{$2004 / 05$} & 18 & 22 & 1.95 & 0.77 & 0.80 & 1.89 & 0.972 & 1.78 \\
\hline & & $19^{*}$ & 2.00 & 0.76 & 0.79 & 1.93 & & \\
\hline & & $3^{* *}$ & 1.67 & 0.80 & 0.83 & 1.6 & & \\
\hline
\end{tabular}

${ }^{*}$ First Brood, ${ }^{* *}$ Second Brood 
Table 2. Body mass of saddleback nestlings near fledging and body mass of male and female juvenile saddlebacks approximately three months after fledging over the three years following the population crash in 2002.

\begin{tabular}{|c|c|c|c|c|c|c|}
\hline \multirow[t]{3}{*}{ year } & \multicolumn{6}{|c|}{ fledgling body mass } \\
\hline & \multicolumn{2}{|c|}{ pre-fledge ( $\sim_{17}$ days $)$} & \multicolumn{2}{|c|}{ post-fledge male } & \multicolumn{2}{|c|}{ post-fledge female } \\
\hline & $n$ & $\mathrm{~g}$ & $n$ & $\mathrm{~g}$ & $n$ & $\mathrm{~g}$ \\
\hline 2003 & 10 & 62.65 & 9 & 79.67 & 9 & 73.22 \\
\hline 2004 & 16 & 62.93 & 2 & 84.00 & 3 & 74.60 \\
\hline 2005 & 10 & 63.25 & 5 & 80.90 & 7 & 70.29 \\
\hline
\end{tabular}

$P<0.01$ : Figure $2 \mathrm{~b}$ ). There was also a significant difference between years in coccidia prevalence $\left(\mathrm{H}_{2,60}=18.29, \mathrm{P}<\mathrm{0.001}\right)$ with coccidia oocysts isolated from faecal samples in the year following the crash but none from samples collected in the second and third years (Figure 2c). No intestinal nematodes were found and we also did not detect blood parasites from the blood smears for any individual across the three years of the study.

\section{Changes in leucocyte counts between years and seasons}

A number of leucocyte parameters of nestlings changed across the three breeding seasons after the population crash. We found a significant difference between total leucocyte count and year $\left(F_{2,54}=15.74, P<0.001\right)$, with nestlings from the second and third breeding seasons following the crash exhibiting higher total leucocyte counts compared to the breeding season immediately after the crash (Figure $3 \mathrm{a})$. The number of lymphocytes $\left(\mathrm{F}_{2,54}=13.34, P<0.001\right)$, heterophils $\left(\mathrm{F}_{2,54}=29.12, \mathrm{P}<0.001\right)$ and eosinophils $\left(\mathrm{F}_{2,54}=6.38, \mathrm{P}<0.01\right)$ also differed significantly across the three breeding seasons and all increased in nestlings from the first to third year after the crash (Figure $3 \mathrm{~b}-\mathrm{d}$ ). Basophil numbers also changed with breeding season $\left(F_{2,55}=17.33, P<0.001\right.$ : Figure 3e), but in this case nestlings from the second breeding season exhibited higher basophil counts than in either the first or third breeding seasons after the crash. We found no significant difference in $\mathrm{H} / \mathrm{L}$ ratio between years $\left(F_{2,53}=0.26, P<0.05\right)$, although there appeared to be a downward trend (Figure $3 \mathrm{f}$ ).

There were no significant differences between the sexes in any of the blood parameters and all adults were combined in subsequent analyses. However, differences between the breeding and non-breeding seasons were apparent and time of year was controlled in further analyses. There was no significant difference in total leucocyte count, heterophil number or eosinophil number in adult saddlebacks over the three years after the population crash, or between breeding and nonbreeding seasons (all $P>0.05$ : Figure $4 \mathrm{a}, \mathrm{c}, \mathrm{d}$ ). Lymphocyte and basophil counts differed over the three years following the crash but following model simplification, only season remained a significant predictor of variation in lymphocyte number with significantly lower counts of lymphocytes in autumn/winter compared to spring/summer $\left(F_{1,88}=19.39, P<0.001\right.$, Figure $\left.4 \mathrm{~b}\right)$. In contrast, there was a significant difference between years in the number of basophils $\left(\mathrm{F}_{2,84}=3.80, \mathrm{P}<0.05\right)$, with basophil counts higher three years after the crash than in the first two years after the crash (Figure 4e). There was a significant interaction between year and season in basophil counts $\left(F_{2,84}=3.14, P<0.05\right)$, with a higher number of basophils observed for spring/ summer in the third year after the crash (Figure 4e). Finally, H/L ratio differed significantly between seasons $\left(F_{1,88}=23.15, P<0.001\right.$, Fig $\left.4 \mathrm{f}\right)$ and there was a significant interaction between season and year $\left(F_{2,88}=5.67, P<0.01\right)$. While year was not found to be a significant predictor of variation in $\mathrm{H} / \mathrm{L}$ ratio $(P>0.05)$, there was a significant interaction between seasons and year $\left(F_{2,88}=5.67, P<0.01\right)$, such that there was an increase in $\mathrm{H} / \mathrm{L}$ ratio through time for autumn/ winter but not spring/summer. This interaction was most prominent in year three where the H/L ratio was much higher in autumn/winter compared to spring/summer (Figure $4 \mathrm{f}$ ). 

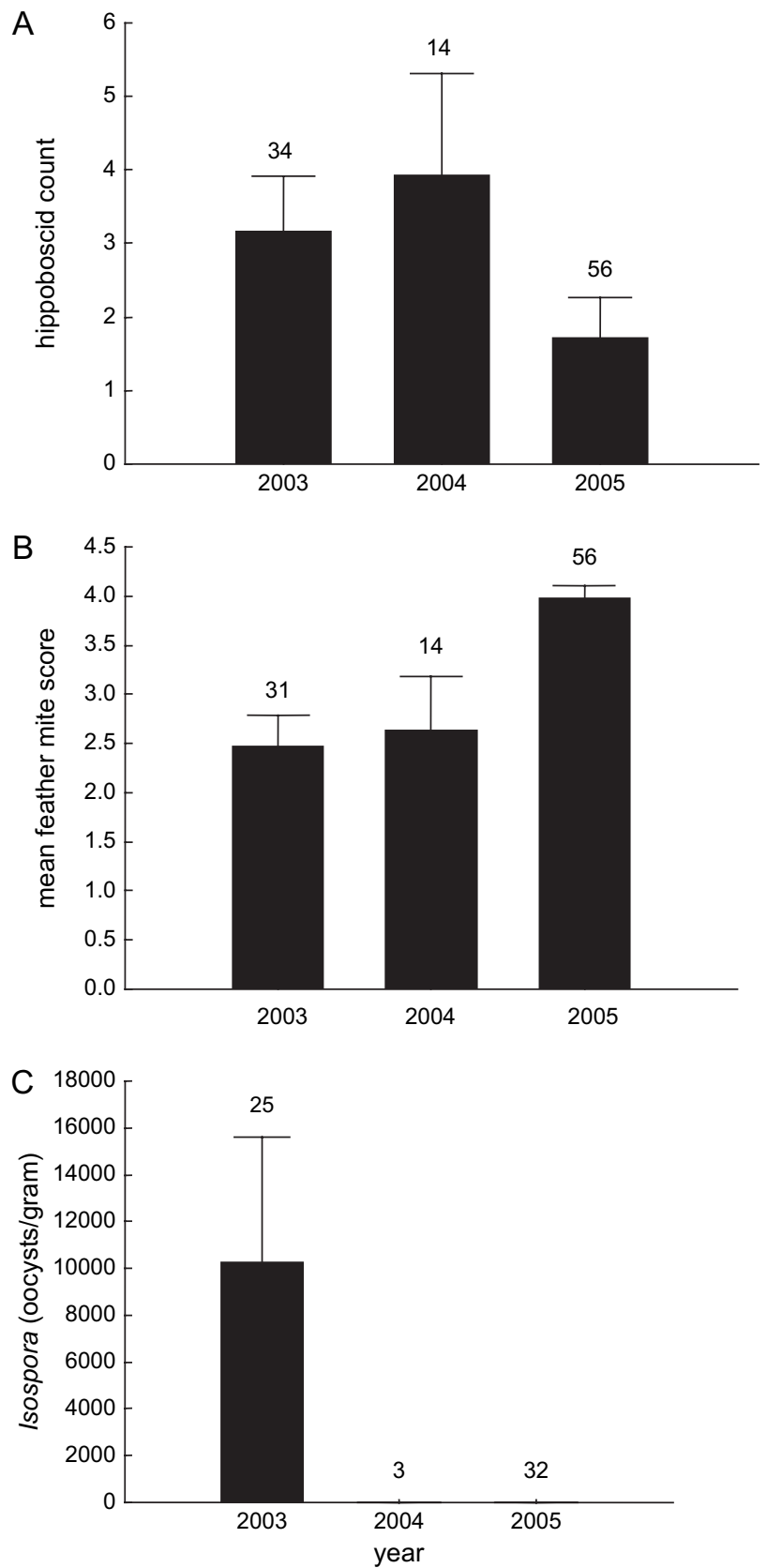

Figure 2. Difference in average loads of (A) hippoboscid flies, $n=104$; (B) feather mites, $n=101$; and (C) coccidia, $n=60$, for the population over the three years following the 2002 population crash. The error bars denote standard error and the numbers above the bar refer to the sample size. 

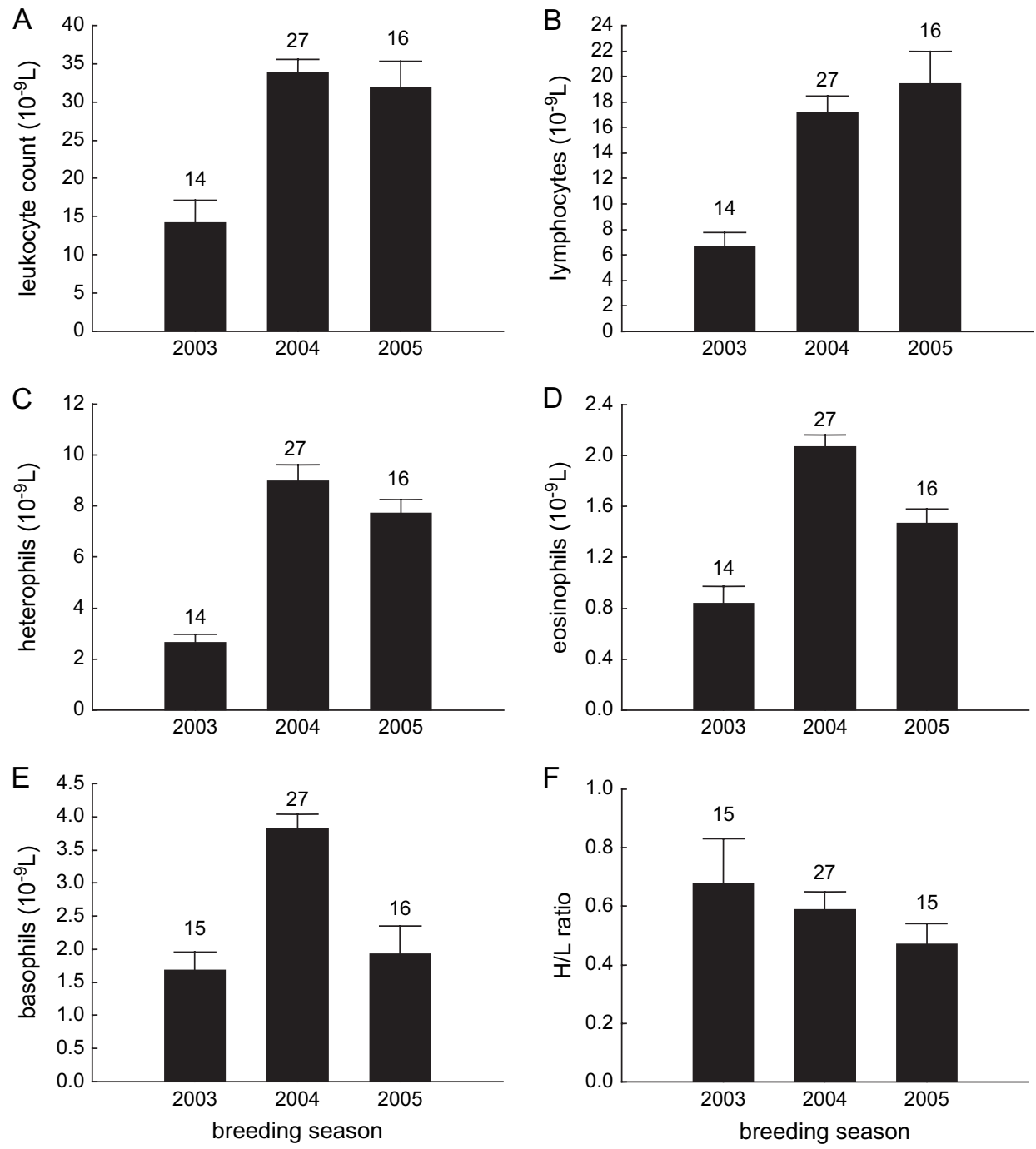

Figure 3. Nestling blood profiles showing differences between nestlings from the three breeding seasons following the population crash in mean counts of (A) total leucocytes, $n=57$; (B) lymphocytes, $n=57$; (C) heterophils, $n=57$; (D) eosinophils, $n=57$; (E) basophils, $n=58$ and (F) $\mathrm{H} / \mathrm{L}$ ratio, $n=56$ for the population. The error bars denote standard error and the numbers above the bars refer to the sample size.

\section{Discussion}

The South Island Saddleback population on Motuara Island showed a remarkable ability to recover after a catastrophic decline. After the population dropped by over $60 \%$ within a twomonth period, the population rapidly increased again, so that within three years after the crash, the total number of birds was similar to that prior the crash. Despite a rapid increase in population size following the crash, we found no significant changes in clutch size or nesting success over the course of our study and the number of fledglings produced per pair appeared to have actually 

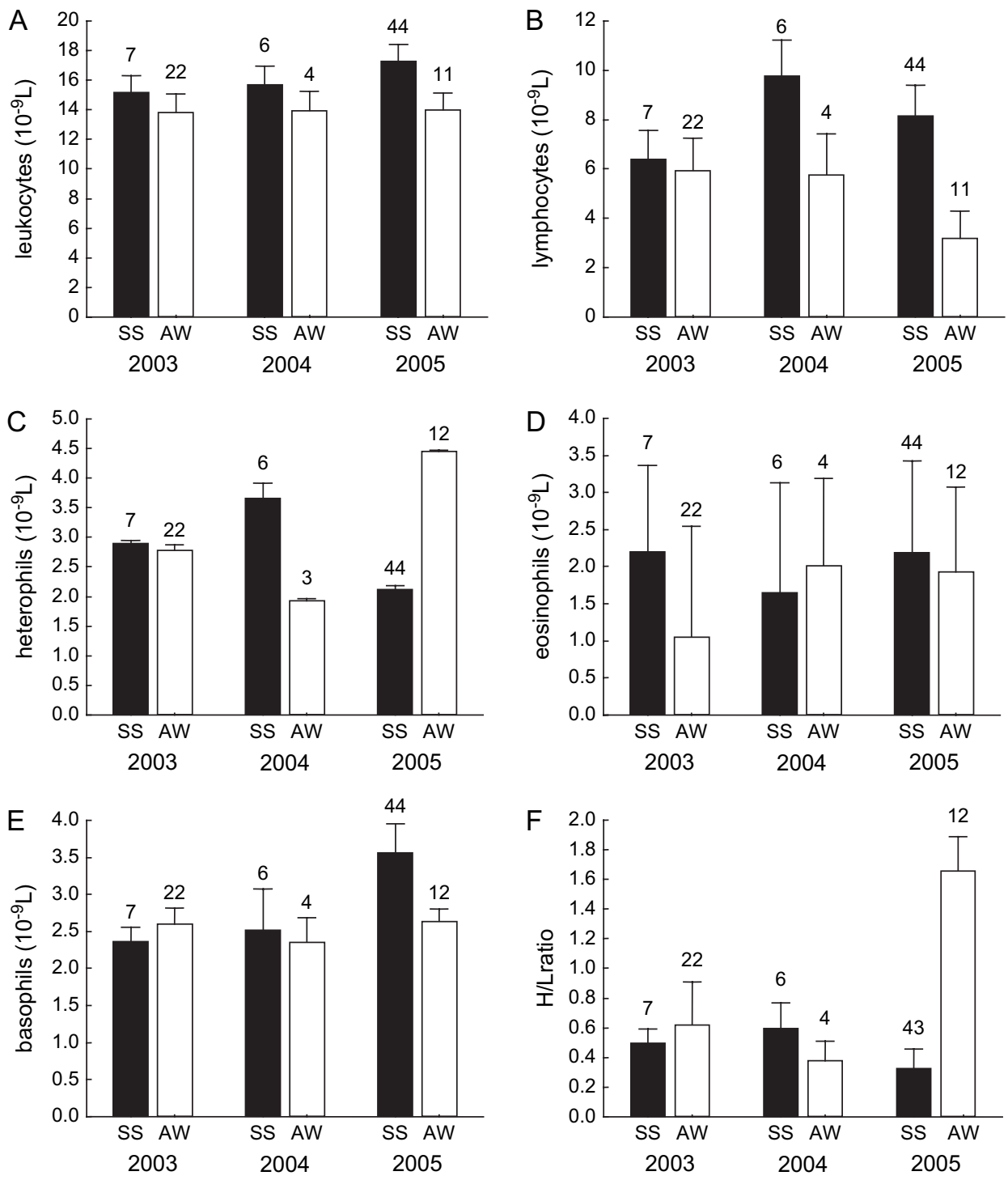

Figure 4. Mean adult blood profiles for the Motuara saddleback population showing seasonal differences (autumn/winter [AW: open bars] and spring/summer [SS: closed bars]) for the three years following the 2002 population crash for (A) total leucocyte count; (B) lymphocytes; (C) heterophils; (D) eosinophils; (E) basophils; and (F) H/L ratio. The error bars denote standard error and the numbers above the bars refer to the sample size.

increased over that observed in an earlier study of the same population before the crash (Hooson and Jamieson 2003). The mass of nestlings was also similar for all three breeding seasons, suggesting there was little effect of increasing population size on productivity, at least within the period we monitored the population. In contrast, we did find evidence to suggest that the increase in population size over the study led to an increasing risk of ectoparasitism and decreases in immunocompetence. Loads of ectoparasitic mites increased in adults over the recovery period 
while changes in the counts of various types of leucocytes in adults suggested they were subject to higher levels of stress as the population increased.

The exact cause of the population crash of saddlebacks on Motuara Island is not certain, although it was likely due to one or more pathogens. As with most other endangered species, the lack of baseline data makes it difficult to recognize abnormal departures in the health of a population, which is why most diseases are discovered after epidemics have already spread through wild populations (Wikelski and Cooke 2006; Altizer et al. 2001). Despite the lack of precrash data, the rapid decline in saddlebacks suggests the cause was an epidemic and the presence of sick birds with coccidia at the time of the crash further supports a pathogen-related cause rather than the result of severe environmental conditions or exotic predators. Although saddlebacks are especially prone to introduced predatory mammals and some populations have disappeared through the re-invasion of predators (Lovegrove 1996b), no exotic predators were ever detected on Motuara Island during or after the crash. The fact that the population later recovered, suggests the decline was not due to predation.

The rapid recovery of the saddleback population we observed on Motuara Island is similar to what has been noted in other newly founded populations of this species (Craig 1994, Taylor et al. 2005). As with other endangered New Zealand birds, the translocation of saddlebacks between islands has been used extensively to create new populations (Lovegrove 1996a). For example, the South Island Saddleback now occurs on 15 different islands, all of which are descended from a single source population (Hooson and Jamieson 2003). The number of saddlebacks used to found new populations has varied between six and 188 individuals (average $=34$; Taylor et al . 2005), but the high survival of translocated birds and their high rate of reproductive success has seen most increase rapidly and reach carrying capacity within a few years (Hooson and Jamieson 2003; Armstrong et al. 2005). As the crash of the Motuara Island population of saddlebacks to $\sim 60$ birds is similar to the number used in numerous successful translocations, it might be expected the population would increase in a fashion similar to newly founded populations. However, translocations generally use healthy birds (or at least not outwardly sick), and it was not certain at the start of this study whether the surviving birds on Motuara would show the same capacity for population re-growth, especially as some of the survivors tested positive for coccidia (W. Cash, Marlborough Conservancy.). Our results show that this was clearly not the case, with the population exceeding its pre-crash level within three years.

The lack of a decline in nesting success and clutch size as the population recovered suggests reproductive success in this species is not density dependent (at least over the range of densities observed in this study). However, as we did not map territory boundaries accurately enough to measure density directly, we cannot rule out changes in density as a factor in our results. In the first year after the crash, large areas of the island lacked saddleback territories altogether and much of the population increase over the three years was simply due to formerly vacant areas becoming reoccupied. By the end of the third year, all areas of the island appeared occupied but whether further increases in population size occur and lead to higher density is not known and needs to be studied further. A study of the North Island Saddleback over a period of six years on Mokoia Island did find increasing negative effects of higher density on survival (Armstrong et al. 2005) and it would seem likely that similar effects might appear in the Motuara Island population over the next few years. Although based on only two years of data, the apparent reduction in number of new recruits to the population also suggests increasing competition and exclusion of young birds, while the increase in feather mite loads, and changes in leucocyte parameters are consistent with increasing density dependent effects. The lower rate of offspring production observed by Hooson and Jamieson (2003) before the crash compared to our observations may also have been due to higher competition although these authors suggest that low productivity may have been negatively affected by a drought at the time.

One of the findings of our study was the increase in feather mite load as the population recovered. Feather mites are specialised, obligatory ectoparasites of a bird's plumage (Dabert and Mironov 1999), feeding on feather oils as well as bacteria and fungal spores trapped in the oil 
(Jovani et al. 2001). It has been suggested they exert little direct harm on hosts (Blanco and Tella 2001; Jovani et al. 2001) and are possibly even beneficial (Harper 1999; Blanco and Tella 2001). For example, feather mites may provide a service to hosts by removing old oil and detritus that might otherwise accumulate on the feathers and lead to a proliferation of pathogenic organisms. The presence of high numbers of feather mites could nevertheless provide an indicator of birds in poor physiological condition (Blanco and Tella 2001) or be symptomatic of a crowded environment, although it is also known that microclimatic and seasonal changes are also known to affect feather mite numbers (Wiles et al. 200o). Whether the increase in feather mite loads in saddlebacks is indicative of a decrease in their condition is not clear although the concomitant decline in some blood parameters suggests this may be the case. Further work is required to better understand the nature of the relationship between high feather mite loads and whether this parasite is directly harmful to saddlebacks, and if not, whether its increase is symptomatic of more pathogenic organisms increasing in the population.

In contrast to feather mites, coccidia oocysts declined in faecal samples and disappeared by the second and third years after the crash. A possible interpretation could be that this population has developed immunity to the parasite. Alternatively, the low population density immediately after the crash may have limited transmission below that necessary for the parasite to survive, as is the case with many species-specific parasites (Altizer et al. 2001; Cleaveland et al. 2002). The apparent disappearance of the parasite, together with the population's rapid recovery to above its pre-crash size, could lead one to conclude the disease has run its course and this population is no longer under threat. However, even if survivors of the crash developed immunity to coccidia, the increasing proportion of immunologically naïve post-crash recruits to the population ( $>68 \%$ by the end of three years) will mean this effect is short lived and the population again vulnerable to the parasite should it be reintroduced. Increasing population size as the population recovers should also facilitate transmission of parasites that require a critical host population density to persist (Armbruster and Reed 2005). How coccidia were introduced to Motuara Island and spread in saddlebacks is unknown, although the crash coincided with a reduction in natural water sources on the island due to dry conditions (pers. obs., see also Hooson and Jamieson 2003) which may have forced individuals to congregate at the stagnant water sources remaining, thereby facilitating the transmission between both individuals of the same species and between species (Dobson and Foufopoulos 2001). While saddlebacks are poor fliers, thus making immigration and emigration from Motuara impossible without human intervention, other introduced and native species are readily able to fly between the island and mainland and could introduce any variety of diseases, including coccidia. Thus the risk of the introduction of a new parasite, or reintroduction of a previously present parasite, is high (Altizer et al. 2001; Swinnerton et al. 2005) and there is clearly a need to monitor saddleback populations for coccidian and other diseases that might erupt again in the future.

The H/L ratio is a measure of physiological stress and was found to increase in adult saddlebacks as the population recovered. Basophil numbers in adults also increased across the three years of the study, and while little is known about the function of avian basophils, there is evidence linking high numbers of basophils to increased stress (Maxwell 1993; Fudge 2000). These changes in the levels of leucocytes could indicate an increased risk to new epidemics as prolonged periods of physiological stress are believed to have an influence on disease resistance by depleting lymphoid cells which play a key role in the cell-mediated and humoral immune responses (Wikelski and Cooke 2006). While some stress is normally expected with seasonal changes (e.g. increasing energy required for reproduction or surviving winter), it is difficult to say whether the apparent increasing levels of stress over the three years of our study will increase the risks of future disease outbreaks. The lack of baseline data on blood parameters makes it difficult to predict at what levels of stress such risks are likely to increase, and whether other aspects of the immune system are similarly compromised.

In contrast to adult birds, blood parameters and growth of nestlings and fledglings appeared to be less affected by the increase in population size. Instead H/L ratio remained relatively stable 
and leucocyte and lymphocyte counts increased suggesting little change in stress levels. It is possible that higher leucocyte and lymphocyte counts could arise from some individuals hosting a disease or parasite, however it is unlikely in this case since we found no physical evidence that the population was suffering from any disease or parasite and all individuals included in the final analysis had blood counts within the normal range for this species. Alternatively the parent birds may have been in poor condition during the first breeding season following the crash and this could have been reflected in the health of the offspring (as measured by leucocyte counts) via reduced parental care. This could also explain why there appeared to be no second broods during the initial breeding season following the crash. In contrast, by the second and third breeding seasons after the crash, this effect on leucocyte counts had disappeared. It should be noted that both the pre-fledge mass and post-fledge mass of nestlings did not differ significantly among years, suggesting that the changes in nestling blood profiles (and adult condition) did not translate into reduced nestling growth.

\section{Conclusion}

Given the importance of islands to the conservation of endangered wildlife in New Zealand and elsewhere, it is crucial that the dynamics between potential hosts and their pathogens are better understood. Many endangered species now exist only on islands and, as our study of the collapse and recovery of a saddleback population shows, may be at risk of pathogen epidemics that could compromise their survival. Conservation managers not only need to establish monitoring programmes to obtain baseline data that facilitates early detection of increasing stress levels and declining health (Wikelski et al. 2004), but also put into place procedures for preventing pathogen introduction and protocols for dealing with outbreaks should they occur. A better understanding of the role of pathogens in small isolated populations like that of saddlebacks may also help in selecting the best individuals to use to found new populations, to determine how large island populations need to be to reduce the risk of extinction, and whether culling or removal of individuals should be used to prevent overcrowding and maintain populations below the threshold at which epidemics are likely to develop.

\section{Acknowledgements}

We thank Karin Ludwig, James Muir, Andrew Thomas, Camille Truong, Nicolas Margraf and Pascale Michel for assistance in the field. Thank you to Jason Tylianakis and Raphael Didham for statistical help and Brett Gartrell for providing haematological advice. The Department of Conservation granted permission to work on Motuara Island and we thank Bill Cash, Mike Aviss and the staff of the Marlborough Conservancy for their support. New Zealand Veterinary Pathology Ltd (Hamilton) assisted with faecal analyses and Medlab Hamilton Ltd and Southern Community laboratories (Christchurch) provided laboratory space and use of equipment. Funding was provided by the Royal Society of New Zealand, the Royal Forest and Bird Society of New Zealand and the University of Canterbury.

\section{References}

Altizer, S., Foufopoulos, J. and Gager, A. (2001) Conservation and diseases. Pp. 109126 in S. A. Levin, ed. Encyclopedia of biodiversity. San Diego: Academic Press.

Armbruster, P. and Reed, D. H. (2005) Inbreeding depression in benign and stressful environments. Heredity 95: 235-242.
Armstrong, D. P., Davidson, R. S., Perrott, J. K., Roygard, J. and Buchanan, L. (2005) Density-dependent population growth in a reintroduced population of North Island saddlebacks. J. Anim. Ecol. 74: 160-170.

Bertram, M. G. (2000) Measuring annual reproductive success in birds. Condor 102: 470-473. 
Blanco, G. and Tella, J. L. (2001) Feather mites on birds: costs of parasitism or conditional outcomes? J. Avian Biol. 32, 271-274.

Cleaveland, S., Hess, G. R., Dobson, A. P., Laurenson, M. K., McCallum, H. I., Roberts, M. G. and Woodroffe, R. (2002) The role of pathogens in biological conservation. Pp. 139-150 in P. Hudson, A. Rizzoli, B. Grenfell, H. Heesterbeek and A. P. Dobson, eds. The ecology of wildlife diseases. Oxford: Oxford University Press.

Craig, J. L. (1994) Meta-populations: is management as flexible as nature? Pp. 50-66 in P. J. S. Olney, G. M. Mace, and A. T. C. Feistner, eds. Creative conservation: interaction management of wild and captive animals. New York: Chapman and Hall.

Dabert, J. and Mironov, S. V. (1999) Origin and evolution of feather mites (Astigmata). Exp. Appl. Acarol. 23: 437-454.

Dobson, A. and Foufopoulos, J. (2001) Emerging infectious pathogens of wildlife. Phil. Trans. Roy. Soc. Lond. Series B 356: 10011012.

Frankham, R. (1998) Inbreeding and extinction: Island populations. Conserv. Biol. 12: 665-675.

Fudge, A. M. (2000) Laboratory medicine: avian and exotic pets. Philadelphia: W.B. Saunders Company.

Gross, W. B. and Siegel, H. S. (1983) Evaluation of the heterophil/lymphocyte ratio as a measure of stress in chickens. Avian Dis. 27: 972-979.

Hale, K. A. and Briskie, J. V. (2007) Decreased immunocompetence in a severely bottlenecked population of an endemic New Zealand bird. Anim. Conserv. 10: 2-10.

Harper, D. G.C. (1999) Feather mites, pectoral muscle condition, wing length and plumage coloration of passerines. Anim. Behav. 58: $553-562$.

Heather, B. D. and Robertson, H. A. (2000) The field guide to the birds of New Zealand. Auckland: Viking.

Higgins, P. J., Peter, J. M. and Cowling, S. J. (2006) Handbook of Australian, New Zealand and Antarctic birds: Vol. 7 A Boatbill to Larks. South Melbourne: Oxford University Press.

Hooson, S. and Jamieson, I. G. (2003) The distribution and current status of $\mathrm{New}$
Zealand Saddleback Philesturnus carunculatus. Bird Conserv. Internatn. 13: 79-95.

Hooson, S. and Jamieson, I. G. (2004) Variation in breeding success among reintroduced island populations of South Island saddlebacks Philesturnus carunculatus carunculatus. Ibis 146: 417-426.

Horak, P., Tegelmann, L., Ots, I. and Moller, A. P. (1999) Immune function and survival of great tit nestlings in relation to growth conditions. Oecologia 121: 316-322.

Hutson, A. M. (1984) Keds, flat-flies and batflies. London: Royal Entomological Society of London. RES Handbook for the Identification of British Insects Volume 1o Part 7. Jovani, R., Tella, J. L., Sol, D. and Ventura, D. (2001) Are hippoboscid flies a major mode of transmission of feather mites? J. Parasitol. 87: 1187-1189.

Lovegrove, T. G. (1996a) Island releases of saddleback Philesturnus carunculatus in New Zealand. Biol. Conserv. 77: 151157.

Lovegrove, T. G. (1996b) A comparison of the effects of predation by Norway (Rattus norvegicus) and Polynesian rats (R. exulans) on the saddleback (Philesturnus carunculatus). Notornis 43: 91-112

Lucas, A. M. and Jamroz, C. (1961) Atlas of avian hematology. Washington: United States Department of Agriculture, Agriculture Monograph25.

Maxwell, M. H. (1993) Avian blood leucocyte responses to stress. World's Poul. Sci. J. 49: 34-43.

Miller, P. S. (1994) Is inbreeding depression more severe in a stressful environment? Zoo Biol. 13: 195-208.

Newman, D. G. (1980) Colonisation of Coppermine Island by the North Island saddleback. Notornis 27: 146-147.

Nillson, R. J. (1978) The South Island saddleback. Wildlife: A Review 9: 32-36.

Ots, I. and Horak, P. (1998) Health impact of blood parasites in breeding of great tits. Oecologia 116: 441-448.

Swaggerty, C. L., Ferro, P. J., Pevzner, I. Y. and Kogut, M. H. (2005) Heterophils are associated with resistance to systemic Salmonella enteritidis infections in genetically distinct chicken lines. FEMS Immunol. Med. Micro. 43: 149-154. 
Swinnerton, K. J., Greenwood, A. G., Chapman, R. E. and Jones, C. G. (2005) The incidence of the parasitic disease trichomoniasis and its treatment in reintroduced and wild pink pigeons Columba mayeri. Ibis 147: 772-782.

Taylor, S. S., Jamieson, I. G. and Armstrong, D. P. (2005) Successful island reintroductions of New Zealand robins and saddlebacks with small numbers of founders. Anim. Conserv. 8: 415-420.

Tompkins, D. M., Mitchell, R. A. and Bryant, D. M. (2006) Hybridization increases measures of innate and cell-mediated immunity in an endangered bird species. J. Anim. Ecol. 75: 559-564.

van Riper, C., van Riper, S. G., Goff, M. L. and Laird, M. (1986) The epizootiology and ecological significance of malaria in Hawaiian land birds. Ecol. Monogr. 56: 327-334.

Walberg, J. (2001) White blood cell counting techniques in birds. Sem. Avian Exotic Pet Med. 10: $72-76$.
Warner, R. E. (1968) Role of introduced diseases in extinction of endemic Hawaiian avifauna. Condor 70: 101-120.

Wikelski, M. and Cooke, S. J. (2006) Conservation physiology. Trends Ecol. Evol. 21: 38-46.

Wikelski, M., Foufopoulos, J., Vargas, H. and Snell, H. (2004) Galapagos birds and diseases: invasive pathogens as threats for island species. Ecol. Soc. 9, [online] URL: http:www.ecologyandsociety.org/volg/issi/ art5.

Wiles, P. R., Cameron, J., Behnke, J. M., Hartley, I. R., Gilbert, F. S. and McGregor, P. K. (200o) Season and ambient air temperature influence the distribution of mites (Proctophyllodes stylifer) across the wings of blue tits (Parus caeruleus). Can. J. Zool. 78: 1397-1407.

Woerpel, R. W. and Rosskopf, W. J. (1984) Clinical experience with avian laboratory diagnostics. Vet. Clinics N. Am.: Small Anim. Prac. 14: 249-286.

\section{KATRINA A. HALE*}

School of Biological Sciences, University of Canterbury, Private Bag 480o, Christchurch, New Zealand.

\section{JAMES V. BRISKIE}

School of Biological Sciences, University of Canterbury, Private Bag 4800, Christchurch, New Zealand.

*Author for correspondence; email: kthale@wildmail.com

Received 3 April 2008; revision accepted 15 October 2008 